\title{
Conjunctive use of organic and inorganic nutrient management on economics and quality of hybrid rice (Oryza sativa L.)
}

\author{
Dinesh Pandey*, Anjum Ahmad, J. K. Chauhan and N. Pandey \\ Department of Agronomy, Indira Gandhi Krishi Vishwa Vidyalaya, Raipur (C.G.) India
}

\begin{abstract}
Field investigation was carried out during kharif 2002 and 2003 at research farm, IGAU, Raipur (C.G.). The experiment aimed at comparing performance of different levels of inorganic fertilizer and its conjunction with different organic fertilizers. Results showed that application of 100:60:40 $\mathrm{kg} \mathrm{NPK} \mathrm{ha}^{-1}$ in conjunction with PM gave the highest value of KLAC, ER and amylose content, which was comparable to inorganic fertilizer level of 100:60:40 kg NPK ha ${ }^{-1}$ applied along with FYM or blending of $\mathrm{N}$ with cow dung. The hulling and milling percent was also increased under these combinations. The highest input cost, net profit and per rupee investment was found under 150:80:60 $\mathrm{kg} \mathrm{NPK} \mathrm{ha}^{-1}$ followed by application of 100:60:40 $\mathrm{kg} \mathrm{NPK} \mathrm{ha}^{-1}$ along with PM.
\end{abstract}

Key Words ::- FYM, Poultry manure, Cow-dung urine mixture, Blue green algae, Phosphorus solubilizing bacteria, Hybrid rice

View Point Article : Pandey, Dinesh, Ahmad, Anjum, Chauhan, J.K. and Pandey, N. (2021). Conjunctive use of organic and inorganic nutrient management on economics and quality of hybrid rice (Oryza sativa L.). Internat. J. agric. Sci., 17 (2) : 424-429, DOI:10.15740/ HAS/IJAS/17.2/424-429. Copyright@2021: Hind Agri-Horticultural Society.

Article History : Received : 01.03.2021; Revised : 04.03.2021; Accepted : 17.03.2021

\footnotetext{
* Author for correspondence :
} 